as to the safe use of the product. The Ministry publishes annually a list of approved materials, the most recent of which has now become available (List of Approved Products 1964 for Farmers and Growers. Pp. 123. Pinner, Middlesex: Ministry of Agriculture, Fisheries and Food, 1964). The booklet is divided into five sections: insect. ioides and acaricides, fungicides, herbicides, seed dressings and miscellaneous produets which include slug and snail baits, growth regulators, fruit-setting compounds, nematioides, rooting hormones, soil sterilants, wetters and wound-sealing materials. Approved proprietary products in their different formulations, for example, dusts, liquids and wettable powders, are listed with each chemical, together with notes on handling precautions and phytotoxicity.

\section{Veterinary Non-proprietary Names}

THE British Veterinary Codex Revision Committee has adopted the following non-proprietary names for the veterinary substances indicated.

\begin{tabular}{|c|c|}
\hline $\begin{array}{c}\text { Non-proprietary } \\
\text { name }\end{array}$ & $\begin{array}{c}\text { Other } \\
\text { names }\end{array}$ \\
\hline Coumaphos & $\begin{array}{l}\text { 3-Chloro-4-methyl-2-oxo-2H-1-benzopyran-7-yl diethyl } \\
\text { phosphorothionate; Asuntol; Bayer 21/199 }\end{array}$ \\
\hline Cyacetazide & Cyanoacethydrazide \\
\hline Diaveridine & $\begin{array}{l}\text { 2,4-Diamino-5-(3,4-dimethoxybenzyl)-pyrimidine; } \\
\text { Darvisul }\end{array}$ \\
\hline Dioxathion & $\begin{array}{l}\text { A mixture consisting essentially of cis- and trans-SS'- } \\
\text { 1,4-dioxane-2,3-diylbis(OO-diethyl phosphorothiolo- } \\
\text { thionate); Delnav }\end{array}$ \\
\hline Methyridine & 2-(2-Methoxyethyl)pyridine; Promintic \\
\hline Piperonyl butoxide & $\begin{array}{l}\text { 1-[2-(2-Butoxyethoxy)ethoxymethyl]-4,5-methylene- } \\
\text { dioxy-2-propylbenzene }\end{array}$ \\
\hline Thiabenda & 2-(Thiazol-4-yl)benzimidazole; Thibenzole \\
\hline
\end{tabular}

The non-proprietary names are reported to be free from conflict with trade marks registered in Great Britain and Northern Ireland, and these names, or names resembling these names, will not be registered as trade marks for pharmaceutical products or drugs in those countries. Some of the names, other than the chemical names, appearing in the second column above are registered trade marks. The adoption of a non-proprietary name does not necessarily imply that the British Veterinary Codex Com. mittee recommends tho use of the substance in veterinary medicine or that the substance will be included in the British Veterinary Codex, although if a substance is in. cluded, it is intended that the non-proprietary name shall be the title of the monograph. The British Veterinary Codex Revision Committee has undertaken, at the request of the Association of the British Pharmaceutical Industry, to provide non-proprietary names for veterinary products, and all requests from manufacturers and other interested persons for the provision of such names should be addressed to: the Secretary, British Veterinary Codex Revision Committee, the Pharmaceutical Society of Great Britain, 17 Bloomsbury Square, London, W.C.1.

\section{Industria! Relations in Britain}

THE March issue of the British Journal of Industrial Relations (2, No. 1; 1964) includes a preliminary research note by Dr. Edith Venables on first-year entrants to a local technical college by size of employing firm which indicates a better achievement and greater persistence of students coming from the large firms than can be attributed to higher ability. Very small firms were greatly under-ropresented among day-release students. Improved achievement and persistence in 1960-63 compared with 1957-60 are attributed possibly to growing realization by both employers and employees of the importance of qualifying. Students' dissatisfaction appeared to be most pronounced with the medium-sized firms. Other articles in the same issue describe an investigation by $R$. K. Brown, J. M. Kirkby and K. F. Taylor of the employment of married women and the supervisory role; an analysis by J. D. Handyside and Mary Speak of job satisfaction: myths and realities; and a discussion by Prof. J. Barbash of the elements of industrial relations.

\section{Leitz to market Unicam Spectrophotometers in Germany}

Unicam Instruments, Lid., of Cambridge, members of the Pye Group, have formed an agreement with Ernst Leitz G.m.b.H., Wetzlar, for the marketing of Unicam spectrophotomoters in West Germany. Joint manufacture by Leitz is also envisaged in the agreement, which came into force on April I. Unicam spectrophotometers are now to have the full backing of the Leitz sales and service organization in Germany. Ernst Leitz are important scientific instrument makers, as well as being manufacturers of the well-known 'Leica' camera. 'They already have an interest in spectroscopy which is complement. ary to that of Unicam. The first instruments to be marketed under the new arrangement will be two modern spectrophotometers designed by Unicam at Cambridge, one for the ultra-violet and visible regions and the other for the infra-red. Both companies will retain complete independence of operation in all other fields, but will collaborate closely in the development of the market for spectrophotometers in Germany. The Unicam-Leitz agreement represents a joint effort by British and German companies, the products of which have a world-wide reputation for excellence.

\section{The International Commission on Zoological Nomen- clature}

Notice is hereby given of the possible use by the International Commission on Zoological Nomenclature of its plenary powers in connexion with the following cases, full details of which will be found in the Bulletin of Zoological Nomenclature (21, Part 1, published on March 25, 1964): (1) Suppression of Doris lacinulata Müller, 1776, Doris fasciculata Müller, 1776, and Limax minimus Forskal, 1775; grant of precedence to Cuthonidae Odhner, 1934, over Tergipedidae Bergh, 1889 (Gastropoda). $Z . N .(S$.$) 1044. (2) Designation of a type-species for$ Eubranchus Forbes, 1838; suppression of the generic names Ethation Risso, 1826, Amphorina Quatrefages, 1844, Galvina Alder and Hancock, 1855, and several dubious specific names (Gastropoda). Z.N. (S.) 1102. (3) Suppression of Cavolina Bruguiere, 1791, and emenda. tion to Cavolinia of the generic name Cavolina Abildgaard, 1791 (Gastropoda). Z.N. (S.) 1103 . (4) Suppression of Cratena Bergh, 1864 (Gastropoda). Z.N. (S.) 1105. (5) Suppression of Diaphoreolis Iredale and O'Donoghue, 1923, and Doris pennata Gmelin, 1791 (Gastropoda). Z.N. (S.) 1106 . (6) Designation of a type-species for Hypercompe Hübner [1819] (Insecta, Lepidoptera). Z.N. (S.) 1611. Any zoologist who wishes to comment on any of the foregoing cases shculd do so in writing to the Secretary, International Commission on Zoological Nomenclature, c/o British Musoum (Natural History), Cromwell Road, London, S.W.7, before September 25.

\section{The Zoological Survey of India}

The Zoological Survey of India, which is one of the six scientific surveys sponsored by the Government of India, has during the past 47 years of its existence achieved an international reputation for its contribution to systematic zoology, to zoogeography and to the study of the evolution of the fauna of the India Region. The survey has been fortunate in having a series of distinguished directors, beginning with Dr. Annandale, who was the first director (1916-24). It continued to be a small department and particularly suffered during the recession years, 1931-32, when the strength of the Survey was reduced and the post of the director down-graded to that of superintendent. Until the initiation of the country's five-year development plans, the Survey had a strength of eight or nine specialist officers. During the First FiveYear Plan little development took place except for the addition of two more officers. Plans for the expansion of the activities of the Zoological Survey of India were 